PONTIFÍCIA UNIVERSIDADE CATÓLICA DO RIO DE JANEIRO

\title{
A perspectiva dos consumidores em relação à responsabilidade social da Magazine Luiza influenciada pela pandemia do Covid-19
}

Santiago Ribeiro Serra Vieira

Trabalho de Conclusão de Curso

Centro de CIÊnCIAS SOCIAIS - CCS

DEPARTAMENTO DE AdMINISTRAÇÃO Graduação em Administração de Empresas 


\section{Santiago Ribeiro Serra Vieira}

A perspectiva dos consumidores em relação à responsabilidade social da Magazine Luiza influenciada pela pandemia do Covid-19.

\section{Trabalho de Conclusão de Curso}

Trabalho de Conclusão de Curso, apresentado ao programa de graduação em Administração da PUC-Rio como requisito parcial para a obtenção do título de graduação em Administração.

Orientador(a) : Vivian Peuker Sardon Steinhauser

Rio de Janeiro, Junho de 2021. 
"Justificar tragédias como vontade divina tira da gente a responsabilidade por nossas escolhas".

(Umberto Eco) 


\section{Agradecimentos}

Agradeço e dedico o presente trabalho à minha mãe, Patricia, pelo amor e empenho incondicionais. Sem ela, eu não teria chegado até aqui.

$E$, à minha recém-falecida avó, Maria Fernanda, que nunca perdeu a fé nos meus sonhos e sempre vibrou com a minha felicidade.

Agradeço também ao meu pai, Luís Guilherme, por ser meu maior exemplo de caráter.

À minha irmã do meio, Luísa, por sempre estar na primeira fila da torcida.

À minha irmã mais nova, Maria Eduarda, pela parceria em todos os momentos.

Agradeço à minha namorada, Isabella, pela cumplicidade, amor e carinho.

Ao meu padrinho Fernando e sua esposa Bel, por me apoiarem nessa trajetória.

À Professora Vivian, por cada minuto dedicado à orientação.

A todos(as) os(as) entrevistados(as), que se fizeram disponíveis para o enriquecimento deste estudo.

A todos(as) professores(as) e colaboradores(as) da PUC-Rio que fizeram parte e contribuíram para o meu desenvolvimento pessoal e profissional. 


\section{Resumo}

Vieira, Santiago. A perspectiva dos consumidores em relação à responsabilidade social da Magazine Luiza influenciada pela pandemia do Covid-19. Rio de Janeiro, 2021. 44 p. Trabalho de Conclusão de Curso - Departamento de Administração. Pontifícia Universidade Católica do Rio de Janeiro.

Acredita-se que a pandemia do Covid-19 antecipou mudanças em curso, como a revisão de crenças e valores. Já que estamos diante de um divisor de águas, capaz de gerar transformações profundas no comportamento do consumidor, precisamos rever as práticas das organizações. A Magazine Luiza foi a escolhida como objeto de estudo, visto que participa de um mercado altamente competitivo, e, segundo pesquisa da ESPM Rio, foi a marca mais bem avaliada entre os consumidores durante a pandemia. Por meio de uma pesquisa qualitativa, este estudo tem como objetivo compreender a percepção, o grau de influência e a fidelidade do consumidor a partir do comportamento socialmente responsável da Magazine Luiza.

Palavras- chave

Magazine Luiza, Responsabilidade Social Corporativa, Comportamento do Consumidor, Covid-19, Comércio Eletrônico. 


\section{Abstract}

Vieira, Santiago. Consumers' perspective on Magazine Luiza's social responsibility influenced by the Covid-19 pandemic. Rio de Janeiro, 2021. 44 p. Course Completion Work - Business Department. Pontifical Catholic University of Rio de Janeiro.

It's believed that the Covid-19 pandemic anticipated ongoing changes, such as the revision of beliefs and values. Since we are facing a turning point, capable of generating deep changes in consumer behavior, we need to review the practices of organizations. Magazine Luiza was chosen as the object of study, as it operates in a highly competitive market, and, according to a survey by ESPM Rio, it was the most highly rated brand among consumers during the pandemic. This study aims to understand the perception, degree of influence and consumer loyalty in relation to Magazine Luiza's socially responsible behavior, through a qualitative research.

Keywords

Magazine Luiza, Corporate Social Responsibility, Consumer Behavior, Covid-19, E-commerce. 


\section{Sumário}

1 Introdução 1

1.1. Contexto e problema de estudo 1

1.2. Objetivo do estudo 5

1.3. Objetivos intermediários do estudo 6

1.4. Delimitação do estudo 6

$\begin{array}{ll}\text { 1.5. Justificativa e relevância do estudo } & 7\end{array}$

2 Referencial Teórico $\quad 8$

2.1. Magazine Luiza 8

2.2. Responsabilidade Social Corporativa 10

2.3. Responsabilidade social corporativa e a perspectiva dos grupos de interesse 13

2.4. A pandemia do Covid-19 e as organizações 14

$\begin{array}{ll}\text { 2.5. Marketplace } & 14\end{array}$

3 Metodologia 15

3.1. Tipo de pesquisa 15

3.2. Coleta de dados 15

$\begin{array}{ll}\text { 3.2.1. Limitações do método } & 16\end{array}$

4 Apresentação e análise dos resultados $\quad 18$

4.1. Descrição da amostra e do perfil dos entrevistados 18

4.2. Análise dos resultados 19

4.2.1. Responsabilidade Social Corporativa orientada à comunidade 19

4.2.2. Responsabilidade Social Corporativa orientada ao ambiente natural20

4.2.3. Responsabilidade Social Corporativa orientada ao colaborador 21

4.2.4. Responsabilidade Social Corporativa orientada ao fornecedor 22

4.2.5. Responsabilidade Social Corporativa dirigida à pandemia do Covid- 
4.2.6. Responsabilidade Social Corporativa dirigida ao Comportamento do Consumidor 25

4.2.7. Compras on-line 28

4.2.8. Responsabilidade Social Corporativa e a Magazine Luiza 28

4.2.9. Critérios de escolha de uma loja virtual 30

4.2.10. Perspectiva dos consumidores em relação à responsabilidade social da Magazine Luiza

5 Conclusão

6 Referências Bibliográficas

Anexo 1: Questionário 


\section{Lista de figuras}

Figura 1: Campanha da Magalu contra violência doméstica............................. 5

Figura 2: Dados dos entrevistados ........................................................ 18 


\section{Introdução}

\subsection{Contexto e problema de estudo}

Estamos passando por um momento de transformações rápidas. O mundo mudou e aquele mundo, de antes do coronavírus, não existe mais. Acredita-se que a pandemia acelerou o futuro, antecipando transições que já estavam em curso, como a revisão de crenças e valores. Diante disso, precisaremos repensar o comportamento do consumidor.

A atual crise de saúde pública é um divisor de águas capaz de provocar mudanças profundas na forma que consumimos. Hoje, mais do que nunca, a lucratividade tem como contrapeso a responsabilidade corporativa (KOTLER; KARTAJAYA; SETIAWAN, 2010). Valores como solidariedade e empatia, assim como o questionamento do modelo de sociedade baseado no consumismo e no lucro a qualquer custo, nunca estiveram tão fortes. Será que olhar para a frente está deixando de ser tão importante quanto olhar para os lados? A pandemia reforçou que tudo e todos estão conectados e não dá mais para ser egoísta?

Em um cenário caótico, os consumidores procuram transformar o mundo globalizado em um lugar melhor por meio de suas práticas de consumo. Eles buscam não somente se satisfazer funcional e emocionalmente, mas também espiritualmente por intermédio dos produtos que consomem e das empresas que se relacionam (KOTLER; KARTAJAYA; SETIAWAN, 2010).

Os stakeholders, ou grupos de interesse (entre eles, a comunidade, 0 meio ambiente, os funcionários, os fornecedores e os clientes), têm sido cada vez mais levados em consideração pelas organizações. Há uma demanda crescente para que as empresas sejam responsáveis com seus grupos de interesse (FERREIRA; AVILA; FARIA, 2010). Isto, de certa forma, parece estar relacionado a uma maior atenção dos consumidores às ações e declarações de executivos em relação a esses grupos de interesse. Essa preocupação por parte das empresas aos grupos de interesse, considerando-os nas ações implementadas e de forma ampla, econômica, social e ambiental, é chamada de Responsabilidade Social Corporativa (AGUINIS; GLAVAS, 2012). E também tem se manifestado nos consumidores brasileiros (SERPA; FOURNEAU, 2007). 
Embora a definição de Responsabilidade Social Corporativa esteja relacionada às expectativas econômicas, legais, éticas, entre outras, que a sociedade tem das organizações em determinado momento (CARROLL, 1979), existe a necessidade de avaliar como tais expectativas são direcionadas pelas organizações em benefício dos grupos de interesse (RUPP et al., 2006).

A Teoria dos Stakeholders, em sua origem, considera que os executivos precisam tomar decisões e considerar ações a partir das relações com os grupos de interesse (FREEMAN, 1984). Estes podem ser definidos como "todos os agentes ou grupos que contribuem para o desempenho da organização ou que são, de algum modo, afetados por ela" (SERRA; TORRES; TORRES, 2003, p. 18). Na visão de Freeman (1984), as organizações capturam valor a partir dos grupos de interesse.

Existem duas visões diferentes: a instrumental, de gerenciar os grupos de interesse a favor da empresa; ou a ética, de gerenciar para os grupos de interesse (ESKEROD; HUEMANN; SAVAGE, 2015). Embora haja uma preocupação crescente dos consumidores com a Responsabilidade Social Corporativa, atentando para como as organizações se comportam em relação aos grupos de interesse, as ações dos executivos e suas declarações indicam que, eventualmente, eles se preocupam mais em gerenciar os grupos de interesse do que gerenciar para os grupos de interesse.

No entanto, com a pandemia do Covid-19, será que os consumidores passaram a valorizar ainda mais as organizações que gerenciam para os grupos de interesse?

A atenção dos consumidores às ações das empresas, bem como a como elas se manifestam em relação aos grupos de interesse, tem sido registrada nas mídias tradicionais e sociais. Mesmo no Brasil, por exemplo, segundo a Secretaria de Inspeção do Trabalho (2020), ainda existe uma lista de grandes empresas associadas a trabalho escravo. Dentre inúmeros casos, alguns ficaram famosos, como o da rede espanhola de lojas de roupas e acessórios Zara, que, segundo Schuquel (2017), em 2011 foi acusada de trabalho escravo pelos seus fornecedores. $E$ teve sua imagem afetada mundialmente.

Declarações de executivos também têm o poder de influenciar a imagem das empresas juntos aos consumidores. Uma série de casos, segundo Pacete (2017), mostram que declarações de executivos podem arranhar a imagem de suas empresas.

Tomemos, por exemplo, uma declaração de Evan Spiegel, CEO do aplicativo de mensagens Snapchat. Segundo Spiegel, o grupo não deveria 
investir em países como a Índia, porque o aplicativo era feito para mercados ricos. Tal declaração iniciou uma onda de boicotes por parte de consumidores indianos.

Em 2006, Mike Jeffries, CEO da rede norte-americana de lojas de roupas Abercrombie \& Fitch, disse em uma entrevista que seus produtos eram direcionados a pessoas magras, bonitas e legais e, por isso, se recusava a produzir roupas de tamanhos maiores. Criou-se, então, diversas campanhas contra a marca. Coincidência ou não, com o passar do tempo, a grife viu suas vendas caírem, várias de suas lojas fecharem, seus resultados financeiros se deteriorarem e a pressão popular aumentar, culminando anos depois na demissão de Mike Jeffries.

Segundo Kotler, Kartajaya e Setiawan (2017), o processo de compra está cada vez mais social. Com o aumento da conectividade, os consumidores também buscam informações para além dos canais formais e tradicionais. Nesse caso, aprimorar a conexão com os consumidores é fundamental. Da mesma forma que a web rompeu barreiras físicas e temporais (PIVA JR., 2013), trazendo grandes oportunidades para as organizações, ela também derrubou barreiras em benefício do consumidor. Atualmente as pessoas não se reúnem apenas em comunidades sociais, mas também colaboram entre si (SOLOMON, 2016), criando uma onda de consumidores virtuais cada vez menos passivos em relação às empresas.

Kotler e Keller (2006, p.153) afirmam que "os clientes de hoje são mais difíceis de agradar. Mais inteligentes, conscientes em relação aos preços e exigentes, eles perdoam menos e são abordados por mais concorrentes com ofertas iguais ou superiores".

Com a pandemia do Covid-19, muitos representantes de empresas se manifestaram e suas palavras geraram reações diversas nos consumidores.

Segundo Pati (2020), com a chegada do coronavírus no Brasil e a formação de uma crise sem precedentes, 41 empresas idealizaram, com o apoio de 12 instituições, um movimento chamado "Não Demita", formando uma rede de mais de 4 mil empresas que se comprometeram em não reduzir seus quadros de funcionários durante os meses de abril e maio de 2020. A partir dessas e outras ações, mais de 2 milhões de empregos foram preservados e mais de 8 milhões de pessoas foram positivamente impactadas durante o período. Segundo Batista Jr. (2020), mesmo antes do movimento, Luiza Trajano, empresária brasileira que comanda a rede varejista Magazine Luiza, já se 
mostrava contrária às demissões em massa. E pedia cautela aos empresários durante a pandemia.

Essa atitude, entre outras, fez com que a Magazine Luiza fosse a marca mais bem avaliada pelos consumidores durante a crise. Afinal, em vez de pensar apenas na sobrevivência da empresa, a companhia considerou também o coletivo, segundo pesquisa da ESPM Rio (BASILIO, 2020).

"A pandemia do Covid-19 está afetando profundamente quase todos os aspectos da vida econômica e social globalmente" (BRAMMER; BRANICKI; LINNENLUECKE, 2020, p. 2). Existem, portanto, muitos questionamentos em relação ao pós-pandemia, ao que a sociedade levará desse período. O que se tem certeza é que "funcionários, clientes, fornecedores e comunidades estão observando - e terão memórias longas" (D'AURIA et al., 2020, p. 3).

De acordo com Lima (2020), a Magazine Luiza, uma das maiores varejistas brasileiras, continuou crescendo mesmo diante do cenário desafiador ocasionado pela pandemia do Covid-19. Pela primeira vez, a empresa ultrapassou a marca de $\mathrm{R} \$ 100$ bilhões em valor de mercado, e Luiza Trajano, presidente do Conselho de Administração da organização, foi considerada a mulher mais rica do Brasil pela Forbes, com fortuna avaliada em $R \$ 24$ bilhões. Já a posição de caixa líquido da empresa, saltou de $R \$ 800$ milhões, um ano atrás, para $R \$ 5,8$ bilhões em junho de 2020. Algumas ações podem ter sido fundamentais para tal, como:

- Apostar em inovação digital, o que levou a empresa a ser comparada a gigantes mundiais do e-commerce, como a Amazon e o Alibaba.

- Usar as lojas físicas para retirada de produtos comprados on-line.

- Não demitir e incentivar outras empresas a fazerem o mesmo, como já mencionado.

- Cuidar de seus colaboradores, antecipando férias remuneradas a uma parte dos funcionários, reduzindo os salários do alto escalão da empresa para cobrir possíveis perdas, dobrando o valor do auxílio-creche para 5.500 funcionárias com filhos de até 10 anos que tiveram que trabalhar presencialmente e aumentando os salários das equipes de logística.

- Criar o "Parceiro Magalu", plataforma desenvolvida para que profissionais autônomos e pequenos varejistas pudessem vender seus produtos online.

- Fazer doações milionárias para a compra de produtos e equipamentos à população de baixa renda e hospitais no combate à Covid-19. 
- Desenvolver um discreto botão para a denúncia de violência doméstica e investir na sua divulgação, visto que, com o isolamento social, o número de casos do gênero aumentou significativamente.

- Criar um programa de trainee para negros como forma de promover diversidade racial nos cargos de liderança.

Figura 1: Campanha da Magalu contra violência doméstica

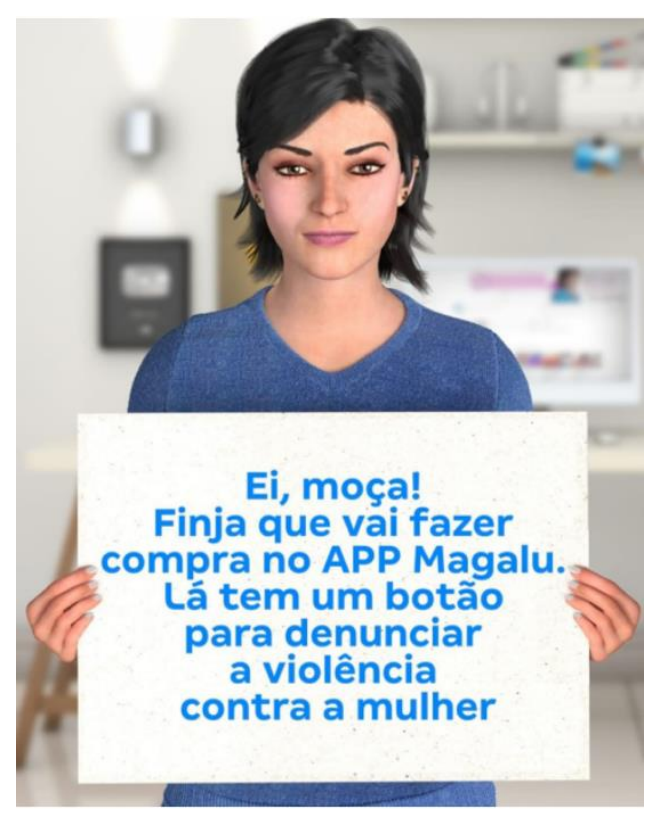

Fonte: Mundo do Marketing, 2020.

\subsection{Objetivo do estudo}

Este trabalho visa compreender a percepção, a tomada de decisão de compra e a fidelidade do consumidor a partir das práticas de Responsabilidade Social Corporativa da Magazine Luiza. E a perspectiva dos grupos de interesse em uma nova realidade pós-pandemia.

Além de entender a percepção dos consumidores em relação às organizações socialmente responsáveis, foram solicitadas informações demográficas relacionadas a idade, sexo, filhos, raça e questões relacionadas ao impacto do Covid-19 para avaliar sua influência na percepção dos respondentes. 


\subsection{Objetivos intermediários do estudo}

O "novo normal" parece indicar novas percepções, algumas de caráter duradouro, e um novo comportamento desejado a partir das organizações. Logo, este estudo também tem como objetivo:

- Possibilitar a compreensão desse efeito e dar indicações que possam confirmar a necessidade de uma nova postura das organizações e daqueles que respondem por elas, principalmente em um mundo cada vez mais conectado, por meio dos avanços tecnológicos, em que certas práticas teriam considerável capacidade de afetar a imagem e o desempenho dessas companhias.

- Analisar quais são os perfis de consumidores mais ou menos afetados por práticas de Responsabilidade Social Corporativa. E entender em que públicos a Magazine Luiza e certas organizações semelhantes devem concentrar seus esforços.

\subsection{Delimitação do estudo}

O presente estudo não possui restrições de gênero, escolaridade ou renda. Para tal trabalho, consideram-se consumidores maiores de idade, residentes na cidade do Rio de Janeiro e compradores de eletrodomésticos da linha branca, como geladeira, fogão, micro-ondas, máquina de lavar, arcondicionado e lava-louças no marketplace on-line da Magazine Luiza.

Essa foi nossa delimitação, considerando que demais marketplaces Ponto Frio, Americanas, Shoptime, Submarino, Casas Bahia, Fast Shop, entre outros - costumam vender eletrodomésticos da linha branca idênticos ou de características similares em um ambiente altamente competitivo, a internet. Sendo assim, existem outros elementos que podem evidenciar a fidelidade do consumidor em relação a estas empresas e a tomada de decisão no momento da compra (para além do fator preço). Em outras palavras, com uma considerável quantidade de empresas confiáveis e com prazos de entregas similares no mercado, que vendem o mesmo tipo de produto, fica mais fácil entender se o consumidor, além do preço, tenderia a preferir essa organização a outra por valorizar ações social ou ambientalmente responsáveis. 


\subsection{Justificativa e relevância do estudo}

Este estudo é relevante ao tentar compreender a percepção do consumidor em relação às empresas que se preocupam em ter um comportamento de Responsabilidade Social Corporativa ético. E o quanto isso afeta, de fato, a imagem e, consequentemente, seus resultados.

Conhecer o perfil dos clientes que são mais ou menos impactados por essas ações (e como eles são impactados) também é relevante para as empresas. Caso seja identificado alto grau de influência de práticas socialmente responsáveis no comportamento de determinados grupos de consumidores, as companhias poderão concentrar seus esforços, assim como divulgar melhor suas ações, para tais perfis de clientes.

O presente trabalho também possui grande relevância acadêmica, já que o cenário pós-pandêmico ainda é muito novo e cheio de mudanças, inclusive na maneira como as organizações se posicionam e os consumidores se comportam. 


\section{Referencial Teórico}

\subsection{Magazine Luiza}

Em 1957, o casal Luiza Trajano e Pelegrino José Donato compraram uma pequena loja de presentes, chamada "A Cristaleira", na cidade de Franca, interior de São Paulo. O nome "Magazine Luiza" surgiu após um concurso de uma rádio local, o que mostra, desde aquela época, grandes diferenciais da empresa: a interatividade e a proximidade com os clientes.

Nas décadas seguintes, além da abertura de outras unidades em sua cidade natal, Franca, o casal expandiu o negócio para outras cidades do interior de São Paulo, como Barretos e Igarapava. Na época, outros familiares também investiram no negócio, o que possibilitou seu crescimento (MARQUES, 2020).

Em 1974, foi inaugurada a primeira loja de departamentos do grupo, com mais de $5.000 \mathrm{~m}^{2}$ (MEDEIROS, 2021)

Após 20 anos de existência, em 1977, a Magazine Luiza já contava com 30 lojas. E, diante do seu crescimento, se fez necessário pensar em novas estratégias de expansão.

Em 1981, com vocação visionária, foi uma das primeiras redes a se informatizar, com a implementação de um sistema de computação nas lojas, o que culminou, cinco anos depois, na criação do seu primeiro centro de distribuição totalmente automatizado. Esse foi um grande passo para consolidar o crescimento da empresa, por meio de uma logística ágil e inteligente.

Em 1991, para preparar o grupo para expansão dos negócios, criou-se a Holding LTD. E, logo em seguida, Luiza Trajano, famosa líder da Magazine Luiza, assumiu o comando e iniciou uma transformação no modelo de gestão da rede.

Nesse mesmo período, surgia o primeiro modelo de comércio eletrônico do mundo: as lojas eletrônicas, hoje chamadas de lojas virtuais. Anos após, em 1999, a empresa expandiu o negócio para a internet, com a criação do site magazineluiza.com, hoje um dos gigantes do e-commerce no Brasil.

Reconhecida por seu modelo de gestão humanitário e pela valorização dos seus colaboradores, em 1998, a empresa passou a constar na lista das melhores empresas para se trabalhar, pesquisa promovida pela Revista Exame 
em parceria com o Instituto Great Place to Work. E cinco anos depois de entrar para o ranking, alcançou o primeiro lugar da lista.

Em 2003, a Magazine Luiza iniciou um intenso processo de expansão e, entre novas aquisições e inaugurações de novas lojas, nos anos seguintes, se consolidou como uma das maiores do segmento, com 750 unidades espalhadas por todo o território nacional. Além de uma fortíssima presença virtual.

O primeiro passo da empresa no digital foi a implementação de um sistema de vendas por meio de terminais multimídias, com orientação virtual dos vendedores aos clientes. Também em 2003, foi criada a Lu do Magalu, um avatar e assistente virtual de vendas desenvolvido para ser um dos rostos da marca e dar dicas e ajudar os usuários com os produtos. Além disso, em 2006, a Magalu era a única varejista do país com operação omnichannel; ou seja, realizava vendas por meio de diversos canais através de uma única estrutura. Em 2016, o grupo inaugurou o Marketplace Magazine Luiza, integrando mais de 200 vendedores e seus produtos em e-commerce.

No $3^{\circ}$ trimestre de 2020, passou a ocupar o $2^{\circ}$ lugar das maiores empresas de varejo, ultrapassando a varejista B2W, que, no mesmo período, cresceu 55\%, enquanto a Magazine Luiza, 70\%.

Hoje, destacando-se a cada trimestre, o poder da Magazine Luiza, principalmente no digital, é indiscutível (MARQUES, 2020).

No $1^{\circ}$ trimestre de 2021, a varejista anunciou lucro líquido recorrente de $\mathrm{R} \$ 81,5$ milhões, com suas vendas on-line mais que dobrando. Apesar do fechamento de algumas lojas, em consequência da pandemia do Covid-19, as vendas aumentaram $62,8 \%$, para $R \$ 12,5$ bilhões, devido às compras on-line, que representaram $70,3 \%$ desse valor. A receita líquida atingiu $R \$ 8,3$ bilhões e, com grandes investimentos em tecnologia e logística para melhorar a experiência digital do consumidor e elevar o percentual de entregas feitas em um dia, as despesas operacionais ajustadas aumentaram $45 \%$, em relação ao ano anterior. Porém, o resultado ainda foi bem positivo. Em proporção com a receita líquida, as despesas operacionais ajustadas caíram 1,8\% para 20,2\% (ALVES, 2021).

Segundo a parte de compromisso com a sociedade do site da própria Magazine Luiza (s.d.), a varejista pratica inúmeras iniciativas de Responsabilidade Social e/ou Ambiental. Entre elas, destacam-se:

- O desenvolvimento humano e profissional de seus colaboradores.

- Uma carta de parceria, que garante segurança e transparência nas transações com os seus fornecedores. 
- A obrigatoriedade de cláusulas contratuais sobre Responsabilidade Social e Ambiental em todos os contratos da empresa com seus fornecedores e prestadores de serviço.

- A associação com o Instituto Ethos e Akatu, organização da sociedade civil que ajuda as empresas a gerirem seus negócios de forma socialmente responsável.

- O "Carona Amiga", projeto que permite que os colaboradores cadastrem pedidos ou ofertas de carona, com intuito preservar o meio ambiente.

- A "Rede do Bem", projeto que reúne e divulga diversas ações sociais desenvolvidas por colaboradores ou unidades de toda a empresa.

- A autonomia de doações e patrocínios a instituições sociais de cada unidade da varejista.

- O patrocínio de eventos e ações culturais, por meio de incentivo fiscal;

- A doação para a manutenção de hospitais.

- O apoio financeiro a instituições como a ONG Fraca Viva, ONG Secos e Não Molhados, Instituo Pró-Criança, entre outras.

- O apoio a pesquisas acadêmicas em universidades de todo o país.

- A prática de inclusão a fim de garantir a diversidade humana na empresa.

\subsection{Responsabilidade Social Corporativa}

A responsabilidade social corporativa pode ser considerada a aceitação dos gestores da obrigação de não só considerar o lucro e a satisfação dos clientes, mas aceitar o bem-estar da sociedade com o mesmo peso ao avaliar o desempenho da empresa (BOONE; KURTZ, 1998).

Existem duas vertentes principais da responsabilidade social corporativa: a da economia clássica, de acordo com a perspectiva de Milton Friedman (1970), e a da visão socioeconômica (SERPA; FOURNEAU, 2007). Na abordagem econômica, a função da empresa é gerar lucros para remunerar o investimento dos seus acionistas. Segundo Guimarães (1984), Friedman argumenta que:

- O objetivo das empresas em uma economia de mercado, em que a competição é muito acirrada, é a maximização dos lucros.

- As ações dos executivos das empresas devem ser sempre voltadas ao lucro, de forma a melhor remunerar os acionistas. 
- Investimentos por parte da empresa na área social, para qualquer tipo de público (interno ou externo, empregados ou a sociedade), são uma forma de lesar os acionistas e de diminuir seus ganhos.

- Procedendo com responsabilidade social, a empresa estará se "autotributando". Nesse caso, em vez de ser elogiada, ela deveria ser processada.

A abordagem socioeconômica indica que a organização deve promover o bem-estar social (SERPA; FOURNEAU, 2007), concordando com a definição de Boone e Kurtz (1998), anteriormente apresentada. Tal abordagem não desconsidera o lucro, mas vai além dele. De acordo com Guimarães (1984, p. 216, apud DAVIS, 1978), destacam-se cinco aspectos que seriam consensuais:

- A responsabilidade social emerge do poder social. Como as decisões empresariais têm consequências sociais, estando relacionadas ao sistema social global, elas não podem ser tomadas unicamente com base em fatores econômicos. A tomada de decisão deve, obrigatoriamente, se guiar por ações que também protejam os interesses da sociedade. Como as empresas, no desempenho da sua missão, se utilizam de um grande volume de recursos da sociedade, em contrapartida, espera-se que elas façam uso desses recursos em favor do coletivo. As organizações que ignorarem a responsabilidade advinda de seu poder social estarão ameaçadas pela lei de ferro da responsabilidade social, já que "a longo prazo, quem não usa poder de uma maneira que a sociedade considera responsável tenderá a perder esse poder".

- As empresas devem ser abertas em duas direções: para receber os inputs da sociedade e para revelar seus resultados ao público. Tradicionalmente, a empresa tem-se organizado para enviar mensagens e não para recebê-las. É necessário, portanto, procurar entender as necessidades e desejos sociais, e não apenas detectar informações de mercado sobre aspectos relacionados meramente aos tradicionais objetivos econômicos. Da mesma maneira que os resultados econômicos, os resultados sociais das operações das empresas também devem ser divulgados. A proposta operacional é a de elaboração de um balanço social dentro dos modelos do balanço contábil. Na França, a publicação desse balanço é uma obrigação legal para as empresas que possuem mais de 300 empregados. Ele deve fornecer informações como 
salários, condições e segurança do trabalho e política social desenvolvida pela organização.

- Tanto os custos sociais quanto os benefícios de uma atividade, um produto ou serviço devem ser exaustivamente considerados antes de se optar ou não por eles. Se, antigamente, a viabilidade técnica e a lucratividade econômica eram os únicos critérios adotados na tomada de decisão, hoje faz-se necessária a ponderação do efeito social do projeto, que, quando considerável, as partes afetadas possivelmente devem ser envolvidas na tomada de decisão.

- O usuário tem a obrigação de pagar os custos sociais de cada atividade, produto ou serviço incorporados a ele. A sociedade não deve arcar com esses custos. Existirão, entretanto, várias exceções, como quando os custos são mínimos e podem ser ignorados, quando são desconhecidos ou quando a sua avaliação é impossível. Se, porventura, esses custos adicionais advindos dessa prática desencorajarem o consumo, o resultado será ainda mais benéfico, já que custos sociais serão evitados.

- Embora as empresas não tenham uma responsabilidade primária na solução de determinados problemas sociais, elas devem, na medida do possível, prestar assistência à sua solução, ou seja, reconhecer os problemas sociais e contribuir ativamente para saná-los. Como qualquer cidadão, ela se beneficiará de uma sociedade melhor.

Independentemente do comportamento responsável esperado das organizações, atenta-se, cada vez mais, para o comportamento irresponsável. Entre os anos de 1960 e 1970, movimentos ligados a diversas demandas sociais deram início à Responsabilidade Social Corporativa. A partir dos anos 1990, emergiu a perspectiva da Responsabilidade Social Corporativa como uma obrigação dos grupos de interesse. Essa abordagem considera que, no lugar de pensar na sociedade como um todo, as organizações devem pensar naqueles que são direta ou indiretamente afetados pelas suas atividades (CLARKSON, 1995). Ao levar em conta um comportamento mais voltado ao socioeconômico, a organização gerenciará para os grupos de interesse (ESKEROD; HUEMANN; SAVAGE, 2015). 


\subsection{Responsabilidade social corporativa e a perspectiva dos grupos de interesse}

Os trabalhos relacionados à Responsabilidade Social Corporativa têm enfatizado os grupos de interesse em suas definições (MORGESON et al., 2013). Alguns autores defendem que a Responsabilidade Social Corporativa deveria significar responsabilidade social com os grupos de interesse (AKREMI et al., 2018). Essa visão mais recente da Responsabilidade Social Corporativa tem recebido suporte de diversos autores (AGUINIS, 2011). Estes indicam aumento de valor compartilhado (PORTER; KRAMER 2011) e entendem que as organizações podem influenciar para uma sociedade melhor a partir dos grupos de interesse (BOSSE; PHILLIPS; HARRISON, 2009). E até mesmo alcançarem resultados financeiros melhores a partir disso (MARGOLIS; ELFENBEIN; WALSH, 2009).

Em uma situação de compras ou de consumo, raramente decisões não são tomadas. Ou seja, por parte do consumidor quase sempre uma escolha é feita (SCHIFFMAN; KANUK, 2007). Não há dúvidas de que a revolução digital é uma das influências mais significativas sobre o comportamento do consumidor. À medida que mais pessoas ao redor do mundo se conectarem, o impacto da web será cada vez mais relevante (SOLOMON, 2016).

Muitas pesquisas mostram que os produtos de empresas que investem em Responsabilidade Social Corporativa têm a preferência dos consumidores (BHATTACHARYA; SEN, 2004). Alguns estudos indicam, inclusive, que consumidores estariam dispostos a pagar mais por produtos de empresas ética e socialmente responsáveis (CREYER; ROSS, 1997).

Adicionalmente, empresas com comportamento pró-social também influenciam a sociedade e seus consumidores (PENNER; DOVIDIO; PILIAVIN, 2005). Esse efeito pode ainda promover comportamentos similares nos consumidores em termos de doações e em prol de causas sociais (ROMANI; GRAPPI, 2014).

Cialdini e Goldstein (2004) argumentam que essa influência para comportamentos positivos ou negativos pode ser transmitida. Ela, porém, não é só das empresas, mas de membros de grupos que tendem a influenciar outros indivíduos (NOLAN et al., 2008; GINO; AYAL; ARIELY, 2009). Esse efeito, com o avanço das ferramentas sociais, acaba se propagando e influenciando de forma mais rápida, prática e em maior escala. 


\subsection{A pandemia do Covid-19 e as organizações}

A pandemia do Covid-19 surpreendeu a todos em uma escala global. No Brasil, a partir de março de 2020, sob recomendação de órgãos competentes, grande parte população passou a ficar isolada. Com isso, empregos se viram ameaçados e os efeitos econômicos foram negativos, afetando a população em geral. As empresas, por sua vez, se viram ainda mais desafiadas em lidar com crises extremas (WENZEL; STANSKE; LIEBERMAN, 2020).

Um dos aspectos comentados pelas empresas de consultoria foi a preocupação com a Responsabilidade Social Corporativa nos setores ambiental, social, econômico e de estabilidade de colaboradores, assim como a coordenação de relações com a comunidade e fornecedores (DELOITTE, 2020). Independentemente do momento, no mundo pós-Covid-19 os consumidores valorizarão ainda mais as empresas com propósito (SNEADER; STERNFELS, 2020). A pandemia parece ter ensinado às organizações que elas devem se comportar de forma responsável e que, acima de seus resultados de curto prazo, elas precisam entender que estão conectadas com pessoas (D'AURIA et al., 2020).

\subsection{Marketplace}

O e-commerce (ou comércio eletrônico) vem crescendo rapidamente no Brasil. De 2013 a 2017, por exemplo, ele saltou de $R \$ 28,8$ bilhões para $R \$ 47,7$ bilhões. E o número de compradores foi de 31,3 milhões para 55,1 milhões (MCKINSEY\&COMPANY, 2019).

O marketplace é um modelo de negócio em que um website de ecommerce agrupa ofertas de diferentes lojas virtuais, reunindo a experiência de compra, o pagamento e possivelmente a entrega. A diferença dessa modalidade para as demais está no conceito de one-stop-shop, que concentra a mesma experiência de compra, desde a busca ao produto até a cobrança em uma única plataforma, sem direcionar o consumidor a sites de terceiros. Diversas empresas conhecidas, como Americanas, Shoptime e Walmart, utilizam essa categoria de comércio eletrônico, que acaba sendo muito vantajosa para o consumidor, já que combina diversos produtos e marcas em um só lugar, o que facilita a procura pela melhor oferta (ZACHO, 2017). 


\section{Metodologia}

Todas as ciências caracterizam-se pela utilização de métodos científicos. Isto é, conjuntos de atividades sistemáticas e racionais que permitem alcançar o objetivo, com maior segurança e economia ao traçar os caminhos a serem seguidos, detectando erros e auxiliando as decisões dos cientistas (MARCONI; LAKATOS, 2003).

Diante da grande variedade de metodologias possíveis no percurso científico, cada uma delas possui características específicas, quando não opostas, e aplicabilidades próprias, sendo importante classificá-las e ordená-las em certos critérios. Logo, o pesquisador precisa fazer as escolhas e opções metodológicas pertinentes ao seu estudo (RIBAS; OLIVO, 2016).

\subsection{Tipo de pesquisa}

Como anteriormente citado, o principal objetivo deste trabalho é compreender como, no cenário pandêmico atual, a Responsabilidade Social Corporativa das organizações impactou na percepção do consumidor e influenciou em sua fidelidade e tomada de decisão de compra. Amparamo-nos, aqui, nas compras no marketplace virtual do Magazine Luiza, varejista que é referência no seu setor em iniciativas do tipo.

Com o propósito de manter a qualidade do estudo, a metodologia aplicada foi a exploratória de natureza qualitativa por meio de entrevistas pessoais com roteiro semiestruturado. Trata-se, então, de investigação de pesquisa empírica, cuja principal finalidade é a formulação de questões, visando: desenvolver hipóteses, aumentar a familiaridade do pesquisador com o fenômeno e clarificar conceitos (MARCONI; LAKATOS, 2003).

\subsection{Coleta de dados}

A coleta de dados foi feita através de entrevista conduzida por roteiro semiestruturado através do Zoom, aplicativo de videoconferência remota, presencialmente e por ligação telefônica, sendo todas elas gravadas ou anotadas. 
A coleta de dados foi realizada ao longo de oito dias, entre 28 de maio 2021 e 4 de junho 2021. E contou com 21 respostas válidas e 4 inválidas.

Todas as entrevistas gravadas foram posteriormente assistidas, para que um relatório fosse redigido. Este foi relido repetidas vezes e, a cada nova leitura, observações, recomendações e elos com a teoria foram incluídos para a análise.

O presente questionário é composto por 31 perguntas, separadas em duas seções, como apresentado no Anexo I, a fim de delimitar a segunda e última seção aos consumidores de eletrodomésticos da linha branca de lojas virtuais.

O questionário contém questões sociodemográficas (sexo, idade, raça e filhos), perguntas sobre a percepção dos participantes em relação à Responsabilidade Social Corporativa, a Responsabilidade Social Corporativa pós-pandemia do Covid-19, a Responsabilidade Social Corporativa e o Comportamento do Consumidor, compras on-line, percepção sobre a Magazine Luiza, Responsabilidade Social Corporativa centradas na Magazine Luiza, a percepção do consumidor sobre a Magazine Luiza e práticas do gênero, sobre ser ou não cliente do marketplace virtual do Magazine Luiza. Contém ainda perguntas sobre ter, pelo menos uma vez, comprado eletrodomésticos da linha branca no marketplace virtual do Magazine Luiza e sobre Responsabilidade Social Corporativa da Magazine Luiza relacionada ao comportamento do consumidor, com o intuito de compreender a relação entre as práticas sociais e ambientais, os consumidores e, consequentemente, o desempenho da empresa.

Todas as perguntas elaboradas foram baseadas na revisão da literatura, apresentada no capítulo 2 deste trabalho. E, após agrupamento das respostas compatíveis com público-alvo anteriormente citado, foi necessária a transcrição dos dados para um bom entendimento da questão de análise. Sendo assim, pode-se identificar as respostas que, de forma conceitual, podiam ser traduzidas em ideias semelhantes ou comportamentos comuns. Realizamos, então, um cruzamento entre certas informações para a análise do contexto.

\subsubsection{Limitações do método}

A entrevista apresenta algumas limitações, tanto em relação ao grupo quanto em relação a situações que geralmente restringem a extensão e quantidade do estudo (MARCONI; LAKATOS, 2003). 
Todos os participantes são moradores da cidade do Rio de Janeiro. Foram excluídas as respostas de três participantes que nunca compraram um eletrodoméstico da linha branca em um marketplace virtual.

Apesar dessa limitação, mesmo as respostas de participantes que nunca compraram um eletrodoméstico da linha branca na loja virtual da Magazine Luiza podem ser úteis para o estudo, já que mostram a perspectiva dos participantes em relação à Responsabilidade Social Corporativa. Porém, para que apenas 0 público-alvo pretendido fosse selecionado, consideramos somente os participantes que não foram excluídos a partir do critério apresentado.

A maior limitação se deve ao reduzido tamanho da amostras e possíveis características relacionadas a esta, visto que todos os participantes recrutados fazem parte de um círculo social próximo (amigos, familiares, colegas de faculdade e colegas de trabalho). Posto que o grupo de entrevistados é restrito, a pesquisa não traz resposta conclusiva para todos os componentes do universo de consumidores de eletrodomésticos da linha branca do marketplace virtual da Magazine Luiza. Pode-se, portanto, apenas extrair ideias e hipóteses a serem concluídas posteriormente em um novo estudo.

Todas as respostas representam as opiniões dos entrevistados. Logo, não podemos expandir a outros contextos. 


\section{Apresentação e análise dos resultados}

Este capítulo está organizado em duas seções. A primeira apresenta a descrição da amostra e do perfil dos entrevistados. A segunda revela os resultados da pesquisa exploratória gerada a partir das entrevistas.

\subsection{Descrição da amostra e do perfil dos entrevistados}

Vinte e cinco pessoas foram entrevistadas neste estudo, sendo que quatro delas não se enquadraram nos critérios de análise propostos. Os 21 participantes válidos possuem as características demográficas a seguir.

Figura 2: Dados dos entrevistados

\begin{tabular}{|c|c|c|c|c|}
\hline Entrevistado(a) & Sexo & Raça & Idade & Filhos \\
\hline Patricia Serra & Feminino & Branca & 59 anos & Sim \\
\hline Luís Guilherme Vieira & Masculino & Branca & 61 anos & Sim \\
\hline Isabella Arouca & Feminino & Branca & 26 anos & Não \\
\hline Raphael Sampaio & Masculino & Branca & 30 anos & Não \\
\hline Josineide Rodrigues & Feminino & Branca & 50 anos & Sim \\
\hline Ana Maria Alves & Feminino & Negra & 64 anos & Sim \\
\hline Alberto Gatti & Masculino & Branca & 35 anos & Não \\
\hline Amanda Edras & Feminino & Negra & 42 anos & Sim \\
\hline Hannah Caroline & Feminino & Negra & 29 anos & Não \\
\hline Eduardo Barbosa & Masculino & Negra & 28 anos & Não \\
\hline Gabriel David & Masculino & Branca & 23 anos & Não \\
\hline Enzo Celulari & Masculino & Branca & 24 anos & Não \\
\hline Fabio Braz & Masculino & Negra & 42 anos & Não \\
\hline Ana Cristina Vieira & Feminino & Branca & 62 anos & Sim \\
\hline Manuella Arouca & Feminino & Branca & 29 anos & Não \\
\hline Jasmin Mureb & Feminino & Branca & 25 anos & Não \\
\hline Monica Arouca & Feminino & Branca & 55 anos & Sim \\
\hline Renan Ribeiro & Masculino & Branca & 38 anos & Sim \\
\hline Luísa Capanema & Feminino & Branca & 29 anos & Não \\
\hline Maria Cristofaro & Feminino & Branca & 22 anos & Não \\
\hline Alice Lopes & Feminino & Branca & 21 anos & Não \\
\hline
\end{tabular}

Fonte: elaborado pelo autor, 2021.

Todos os entrevistados são residentes, até a data das entrevistas, da cidade e Estado do Rio de Janeiro. 


\subsection{Análise dos resultados}

A análise dos resultados obtidos nas entrevistas, apresentados a seguir, está dividida em nove seções terciárias, quais sejam: Responsabilidade Social Corporativa orientada à comunidade; Responsabilidade Social Corporativa orientada ao ambiente natural; Responsabilidade Social Corporativa orientada ao colaborador; Responsabilidade Social Corporativa orientada ao fornecedor; Responsabilidade Social Corporativa dirigida à pandemia do Covid-19; Responsabilidade Social Corporativa dirigida ao Comportamento do Consumidor; Compras on-line; Responsabilidade Social Corporativa e a Magazine Luiza; e Critérios de escolha de uma loja virtual.

O final deste capítulo também apresenta uma análise sobre a perspectiva dos consumidores em relação à responsabilidade social da Magazine Luiza.

\subsubsection{Responsabilidade Social Corporativa orientada à comunidade}

Por meio das respostas dos entrevistados, observamos certa coerência sobre Responsabilidade Social Corporativa orientada à comunidade, já que todos os entrevistados concordam com a importância de investimento por parte das empresas em causas sociais. E disseram admirar organizações que se comportam dessa maneira.

Além disso, todos os participantes também acreditam na importância de ações de empresas para a melhora do bem-estar das populações nas áreas onde elas atuam. Porém, somente 9 citaram pelo menos uma ação social de forma concreta, em que o tema mais comentado foi o investimento em projetos sociais, como notamos nas seguintes menções dos entrevistados:

Eu acho que as grandes empresas têm que se preocupar com os que mais precisam e investir em projetos sociais que tenham a ver com o posicionamento de marca. É uma forma de fazer o bem, devolver um pouco daquilo que a sociedade proporcionou para ela em forma de lucro e ainda trabalhar o marketing. (Alberto Gatti, 35 anos)

Uma boa empresa, se quiser construir uma boa reputação, ainda mais nos dias de hoje, tem que praticar a solidariedade. Precisa descobrir seu propósito na sociedade e designar parte dos ganhos para ONGs e projetos sociais. A 
gente vive em um mundo tão desigual. Na minha opinião, isso teria que fazer parte de qualquer business no país em que vivemos. (Manuella Arouca, 29 anos)

Todos os entrevistados concordam que, além da obrigatoriedade do Estado, as empresas também devem possuir certo compromisso com ações sociais. No entanto, somente 3 apontaram pelo menos uma ação social de forma objetiva. Entre as obrigações indicadas estão a inclusão de pessoas com deficiência e o combate ao assédio moral ou sexual, tal como se verifica nas seguintes falas:

Sem dúvida, o Estado é o maior responsável nesse quesito, mas também é papel das empresas se interessar pelo assunto. Por mais que não seja obrigatório para todos os tipos de empresas, o certo seria promover a diversidade, contratando pessoas com deficiências que não têm as mesmas oportunidades, por exemplo. (Raphael Sampaio, 30 anos)

Hoje em dia, a gente vê muitos casos de assédio por aí. A Globo, por exemplo, teve um escândalo desses. Às vezes, - Estado não consegue fiscalizar certas coisas e cabe à empresa se preocupar. $O$ combate ao assédio moral ou sexual é uma delas. (Isabella Arouca, 26 anos)

Quando perguntados sobre quais empresas eles admiravam ou se lembravam de se preocuparem com questões sociais, 8 entrevistados mencionaram pelo menos uma companhia. Dentre as 16 empresas indicadas, somente 2 pessoas citaram a Magazine Luiza.

\subsubsection{Responsabilidade Social Corporativa orientada ao ambiente natural}

Todos os 21 participantes concordam com a necessidade de investimento em práticas ecológicas. Disseram tanto admirar quanto dar preferência às empresas que se preocupam com este tema e citaram ações de forma concreta. Entre as mais comentadas estão programas de reciclagem; preferência pelo uso de materiais ecológicos; descarte de resíduos; controle de poluição; e estímulo 
de práticas ambientalmente responsáveis nos colaboradores. Um dos entrevistados comentou:

Estamos, cada vez mais, conscientes com o meio ambiente. Não só a população, mas as empresas também. As empresas têm que formular e adequar seus produtos para tentar corrigir os danos que a gente já causou ao planeta. Elas precisam reciclar, encontrar alternativas sustentáveis para os produtos e tentar medir o impacto que elas causam no meio ambiente. Só assim a gente vai para a frente. (Enzo Celulari, 24 anos)

Quando perguntados que empresas eles admiravam ou se lembravam de se preocuparem com questões ambientais, 12 dos 21 entrevistados mencionaram pelo menos uma. Apesar de 21 empresas terem sido citadas, nenhuma pessoa mencionou a Magazine Luiza.

\subsubsection{Responsabilidade Social Corporativa orientada ao colaborador}

Todos os participantes acreditam que as empresas devam se preocupar com o bem-estar de seus funcionários, mas somente 9 citaram ações de forma objetiva, como a valorização da saúde mental. Eles citaram, por exemplo, a pandemia, envolvendo isolamento social, mudança de rotina e home office. Chamaram atenção ainda para treinamento e desenvolvimento e ambiente de trabalho adequado, como mostrado nas menções a seguir:

Ninguém merece trabalhar em uma empresa que não dá oportunidades. Tem que ter oportunidade. Tem que ter treinamento. Tem que ensinar o funcionário, criar cursos, fazer com que ele se desenvolva lá dentro. A gente tá ali para trocar e para crescer junto. É muito importante ter um ambiente legal para se trabalhar. (Alice Lopes, 21 anos)

Acho muito importante, ainda mais nesse momento (de pandemia), prestar atenção no funcionário. Tudo mudou. A gente teve que ficar dentro de casa, paramos de ir para o escritório. Estamos voltando aos poucos e levou tempo para se acostumar com isso tudo que está acontecendo. Muita gente 
está surtando e os chefes precisam estar mais flexíveis. (Luísa Capanema, 29 anos)

Já quando perguntado quais ações as empresas devem tomar em suas políticas de recrutamento e seleção, 11 entrevistados citaram pelo menos uma, com destaque para inclusão e oportunidades para negros; igualdade de gênero; inclusão e oportunidade para deficientes físicos; oportunidade para os jovens mais inexperientes; e inclusão e oportunidade para indígenas. Os seguintes relatos se destacam:

Eu acho muito importante promover a inclusão. Mais que importante, eu acho necessário. Mais que oportunidade, é uma questão de reparação histórica para nós (negros). E isso não se resume aos negros. Tem que ser com deficientes, indígenas, mulheres. (Hannah Caroline, 29 anos)

As empresas têm de dar mais oportunidades para quem não tem muita experiência. Quem está começando no mercado de trabalho. Não dá para enxergar os jovens só como mão de obra barata, mas dar oportunidade de verdade para quem está começando. (Maria Cristofaro, 22 anos)

Ao cruzarmos certas informações, alguns resultados chamam atenção. São eles:

- A maioria das pessoas que citaram ações de inclusão e oportunidade para negros é negra. Esse resultado sozinho talvez não revele muito, porém se levarmos em consideração que a proporção de brancos e negros na amostra da entrevista é altamente desigual, podemos concluir que o número de negros que citaram o tema é muito maior.

- Todas as pessoas que falaram sobre igualdade de gênero são mulheres.

- Todos os participantes que citaram práticas de oportunidades para jovens inexperientes estão na faixa etária entre 18 e 24 anos.

\subsubsection{Responsabilidade Social Corporativa orientada ao fornecedor}

Notamos uma pequena divergência entre os participantes sobre Responsabilidade Social Corporativa orientada ao fornecedor. Apesar de a 
maioria acreditar no dever das empresas de tomar certas medidas para garantir que seus fornecedores, subcontratados ou prestadores de serviços, onde quer que eles estejam, também se preocupem com ações de cunho social, ambiental ou de boas práticas com seus colaboradores, algumas pessoas acreditam que cada empresa deva focar em suas próprias questões; ou seja, estas não enxergam que isso seja um dever das organizações.

Dos 8 entrevistados que citaram pelo menos uma medida de forma objetiva, as mais comentadas foram a pesquisa prévia para a escolha do parceiro, a fiscalização e cláusulas contratuais com certas obrigações, como se pode verificar na seguinte fala:

Tem que saber quem é que você está colocando para dentro. Não dá só para contratar e pronto. A pesquisa tem que ir além do preço da proposta, porque pode ser ruim para a empresa se associar a uma outra que age mal e, também, deve estar sempre de olho (fiscalizando). (Ana Cristina Vieira, 62 anos)

\subsubsection{Responsabilidade Social Corporativa dirigida à pandemia do Covid-19}

Todos os entrevistados concordam que, em casos de desastres naturais, acidentes ou pandemias, como a de Covid-19, as empresas devam prestar assistência aos mais necessitados. Destes, 17 mencionaram tipos de auxílios, com destaque para auxílios financeiros, doações de produtos e mobilização dos colaboradores. Como disse um dos participantes:

$\mathrm{Na}$ pandemia a gente viu um bando de empresas ajudando. Tem que ajudar mesmo. Tá todo mundo sofrendo e elas (as empresas) têm de se mobilizar como podem, seja com dinheiro, com produto ou mão de obra. (Renan Ribeiro, 38 anos)

Quando perguntados como acreditam que as empresas devem se comportar em relação à sociedade em tempos de Covid-19, todos os participantes souberam responder objetivamente. Entre os temas notabilizados estão: a empatia; a solidariedade; o posicionamento na mídia; a boa 
comunicação e transmissão de informações relevantes para todos os envolvidos; e soluções para os consumidores. Como pode-se observar nas seguintes falas:

A gente sabe quem está preocupado ou não. Há empresas que não estão nem aí e outras mostram empatia, se solidarizam com o que está acontecendo e se posicionam em relação ao problema. Não estou falando de posicionamento político, mas de se solidarizarem mesmo. Tem que mostrar que, por trás daquela marca, existem seres humanos e eles precisam se comunicar de forma adequada para o cenário em que estamos vivendo. (Gabriel David, 23 anos)

Eu acho que elas (as organizações) têm de se preocupar com quem compra. Não adianta achar que está tudo normal. Tem que entender as nossas (clientes) necessidades em um momento como esse. (Luísa Capanema, 29 anos)

Quando questionados sobre como as organizações devem se comportar em relação a seus colaboradores em tempos de Covid-19, ainda que todos os entrevistados acreditem na importância de boas práticas das empresas para com seus funcionários, somente 15 entrevistados indicaram práticas de forma objetiva, com tópicos como: saúde mental dos colaboradores (alguns comentaram sobre a importância da extensão aos familiares); segurança no trabalho (alguns comentaram sobre a importância de não haver distinção entre cargos para tal); empenho para não demitir; e compreensão em casos de atrasos ou tarefas fora do prazo pela mudança repentina na rotina de todos. Os seguintes relatos ilustram alguns desses conteúdos:

Estamos fragilizados. Muitas pessoas estão sofrendo de doenças mentais que nem sabiam que tinham e isso não se resume ao funcionário, mas a toda a família. E não é só a questão mental: estamos com medo de ir trabalhar e passar coronavírus para dentro de casa. De nada adianta o chefe ficar em casa e os funcionários ficarem se arriscando. É papel da empresa se preocupar com isso também. (Ana Cristina Vieira, 62 anos)

Todo mundo está com medo de perder o emprego. A gente viu empresas demitindo em massa e isso afeta qualquer 
um. Se eu fosse empresário, faria de tudo para manter o máximo da equipe nesse período (de pandemia). Eu vi pessoas que tiveram as suas vidas viradas de cabeça para baixo, darem mole no trabalho por causa disso, como atrasar ou entregar um trabalho fora do prazo, e serem mandadas embora. $\mathrm{Na}$ verdade, elas foram mandadas embora porque ela (a empresa) já queria cortar custos. Eu fui uma delas, mas, graças a Deus, consegui um emprego melhor. É um momento muito delicado que pede por compreensão. (Hannah Caroline, 29 anos)

A partir dos cruzamentos dos dados, constatamos que todos os participantes que mencionaram a importância de se estender a familiares, ações como aquelas relacionadas à saúde mental dos colaboradores, possuem filhos.

\subsubsection{Responsabilidade Social Corporativa dirigida ao Comportamento do Consumidor}

Quando questionados sobre que tipos de iniciativas de responsabilidade ambiental ou social os fariam dar preferência a uma empresa na ocasião de compra de um produto ou serviço, todos os participantes mencionaram pelo menos uma atividade concreta, com destaque para programas de reciclagem; produtos ecologicamente corretos; descarte adequado de resíduos; investimentos em projetos sociais; e controle da poluição. Como pode-se observar no seguinte relato:

Antes de comprar um produto, eu costumo saber um pouco mais sobre ele. O plástico, por exemplo: vários produtos que a gente compra são de plástico e o descarte é um problema grave. Vários documentários no Netflix falam disso. A gente está destruindo o nosso planeta e faz parte do nosso papel escolher produtos ecológicos, de empresas que reciclam, que não poluem. (Eduardo Barbosa, 28 anos)

Observamos que, mesmo que a pergunta aborde tanto questões ambientais como sociais, a grande maioria das ações mencionadas está associada ao ambiente natural.

Em relação a quais tipos de escândalos de cunho socioambiental fariam os entrevistados desistirem de comprar em uma empresa, todos os participantes disseram que desconsiderariam a compra caso vazasse alguma informação do 
gênero de alguma organização. Quando solicitados a citaram tipos de escândalos dessa espécie que os fariam desistir da compra, os tópicos mais comentados foram: trabalho escravo; trabalho infantil; descriminação racial; corrupção e escândalos políticos; testes em animais; homofobia; poluição do meio ambiente; desvalorização do colaborador; gordofobia; assédio moral; e maus-tratos contra animais. Entre as falas que se destacam, estão:

Eu mesma comprava na Zara e deixei de comprar durante um tempo, quando descobri que ela tinha trabalho escravo. Na loja Três também. Essa eu nunca mais comprei. Não sei nem se ainda existe. (Isabella Arouca, 26 anos)

Entre tantos supermercados, por que eu vou escolher logo o que é racista e mata cachorro inocente? Perto da minha casa têm uns cinco supermercados, um do lado do outro. No Carrefour, só vou se for o único aberto. (Eduardo Barbosa, 28 anos)

Outro dia eu vi um documentário gringo que fala sobre o trabalho escravo das marcas de chocolate. Nem sei se é assim no Brasil, mas eu me sinto mal quando eu compro um chocolate da Hershey's. Não procurei saber a fundo sobre 0 assunto, mas não compro mais. (Alberto Gatti, 35 anos)

Como pode se aferir das citações anteriores, além dos tipos de escândalos, a grande maioria dos participantes menciona, mesmo sem ser solicitada, vários exemplos de empresas que tiveram suas imagens manchadas por questões afeitas ao gênero. Os casos mais relevantes foram:

- Marca espanhola de vestuário Zara: se envolveu em escândalo, mais de uma vez, por condições de trabalho análogas à escravidão, contratações ilegais, trabalho infantil, condições degradantes e jornadas de trabalho sub-humanas.

- Rede francesa de hipermercados Carrefour: se envolveu em escândalo de racismo, após um homem negro ter sido espancado até a morte por um segurança de uma unidade da empresa em Porto Alegre, Rio Grande do Sul. 
- Marca carioca de vestuário Loja Três: se envolveu em escândalo de racismo, gordofobia, homofobia e assédio moral.

- Marca estadunidense de artigos esportivos Nike: virou sinônimo de trabalho infantil, após a divulgação de uma criança costurando uma bola de futebol da marca.

- Rede brasileira de restaurantes Madero: foi fortemente criticada por ter demitido, logo no início da pandemia do Covid-19, 600 funcionários de uma só vez.

- Rede brasileira de academias de ginástica Smart Fit: boicote de grupos LGBTQIA+ contra o grupo, por suposto envolvimento do proprietário em esquema criminoso a favor do presidente Jair Bolsonaro, após ser um dos alvos da CPMI das Fake News.

- Marca alemã de cosméticos Nivea: escândalo de testes de seus produtos em animais.

- Marca brasileira de vestuário Le Lis Blanc: escândalo de trabalho análogo à escravidão, tráfico de pessoas e trabalho infantil, com a libertação de bolivianos em oficinas clandestinas.

- Rede francesa de hipermercados Carrefour: escândalo de maus-tratos contra animais, após a viralização de um vídeo da morte brutal de um vira-lata, que teria sido espancado e envenenado por um segurança da unidade, na região metropolitana de São Paulo.

- Marca estadunidense de vestuário Abercrombie \& Fitch: escândalo de gordofobia, após seu CEO dizer que mulheres gordas não deviam usar a marca.

- Companhia de alimentos JBS: escândalo de corrupção, pagamentos de propina e delações na operação Lava Jato.

- Companhia estadunidense Hershey's: escândalo de trabalho análogo à escravidão e infantil, pelo fato de grande parte de seu cacau ser proveniente de fazendas africanas que praticam trabalho forçado, sem pagamentos, documentos de viagem ou qualquer conhecimento das pessoas de quando terão permissão para voltar para casa.

Quando questionados o quanto pagariam mais caro por um produto ou serviço de uma empresa reconhecida por ações sociais ou ambientais, em vez de escolher um concorrente que não se preocupa com questões desse tipo, a maioria das pessoas afirmou que pagaria mais caro. Por outro lado, alguns 
poucos disseram que não sabem dizer se estariam dispostos a pagar mais caro pelo produto ou serviço. Dentre os participantes que estariam dispostos a pagar mais caro, grande parte não soube quantificar em porcentagem ou em números absolutos o quanto pagariam. E poucos disseram que desembolsariam entre $5 \%$ e $10 \%$ a mais.

Vale ressaltar que, ao serem perguntados o quanto a mais estariam dispostos a pagar naquela circunstância, nosso intuito foi entender até onde iria sua fidelidade e sua preferência pelas empresas social ou ambientalmente responsáveis. Logo, já era de se esperar que a grande maioria das respostas não viria com valores estipulados.

\subsubsection{Compras on-line}

Quando perguntados sobre a última vez em que fizeram uma compra online, a maioria dos entrevistados respondeu "a menos de uma semana" e "a menos de um mês".

Já quando questionados quantas vezes, aproximadamente, compraram um eletrodoméstico da linha branca em lojas virtuais, a grande maioria dos participantes respondeu entre 2 e 10 vezes.

Vale mencionar que, através do cruzamento das informações, observamos uma maior frequência de compras on-line entre os participantes de faixas etárias mais jovens; mas quando perguntados sobre a compra de eletrodomésticos da linha branca, a faixa etária se eleva.

Quando questionados quantas vezes, aproximadamente, os participantes haviam comprado eletrodomésticos da linha branca, na loja virtual da Magazine Luiza, a grande maioria respondeu que entre 1 e 5 vezes.

\subsubsection{Responsabilidade Social Corporativa e a Magazine Luiza}

Sobre o que os entrevistados acham da Magazine Luiza, a maioria dos participantes disse gostar da empresa. Poucos falaram que não tinham nada a declarar. Dentre os que elogiaram a organização, os tópicos mais comentados são a forma como a marca se comunica; a credibilidade no mercado; os preços competitivos; a liderança feminina; a entrega rápida; o avatar "Lu do Magalu"; o posicionamento sobre questões sociais; e a interação com influenciadores digitais. Como se pode verificar nas seguintes falas: 
Eu gosto da Magazine Luiza. Os preços são bons, eles entregam sempre muito rápido e o Instagram deles é demais. Já viu as fotos da Lu (avatar)? Ela com as celebridades, mostrando os produtos, com vários looks diferentes. Eu adoro. (Isabella Arouca, 26 anos)

O fato de ela ser mulher (Luiza Trajano) já me diz muita coisa. Isso já é exemplo para muitas outras mulheres, e a forma como se posicionam, como fizeram na pandemia, também me agrada. (Patricia Serra, 59 anos)

Ao serem questionados sobre quais práticas de cunho social ou ambiental da Magazine Luiza os participantes se lembravam, nenhum mencionou ações ambientais. Alguns poucos, metade deles negros, inclusive, comentaram sobre o programa de trainee para negros. Logo, diante da desproporcionalidade entre o número de negros e brancos da amostra, como citado anteriormente, ao considerarmos todos os entrevistados, a grande maioria dos negros aponta essa ação, enquanto somente alguns dos brancos a citaram.

Vale salientar que alguns participantes também mencionaram outras ações ao responderem a essa pergunta. Mas, como elas condizem com a questão a seguir, por se tratar de práticas pertinentes à pandemia do Covid-19, certas respostas foram agrupadas no próximo tema.

Quando perguntados sobre quais práticas de cunho social ou ambiental da Magazine Luiza durante a pandemia do Covid-19 os entrevistados se lembravam, algumas pessoas citaram pelo menos uma prática de forma concreta. As mais comentadas são doações milionárias para o combate do coronavírus, a campanha contra a violência doméstica, motivada pelo alto índice de denúncias de mulheres durante o isolamento social, e o comprometimento, no início da pandemia, em não demitir nenhum dos colaboradores.

Me chamou a atenção um botão que eles (Magazine Luiza) criaram na pandemia para mulheres que sofrem violência doméstica. Acho que fizeram várias doações durante a pandemia também, mas não me lembro quanto, quando ou por onde. (Patricia Serra, 59 anos)

Eles não demitiram no início da pandemia. Até criaram uma rede com outras empresas que fizeram o mesmo. Achei 
nobre, ao contrário de algumas como a Havan, pelo que divulgado, que saíram demitindo. (Luis Guilherme Vieira, 61 anos)

Eu sei que doaram muito dinheiro para ONGs. Participaram de algumas lives, se eu não me engano. (Isabella Arouca, 26 anos)

Por meio do cruzamento de informações, identificamos que todos os participantes que abordaram a campanha contra a violência doméstica na pandemia do Covid-19 são do sexo feminino.

Em relação às ações sociais que levaram os participantes a admirar a Magazine Luiza, todos que citaram questões de maneira objetiva repetiram as respostas da pergunta anterior. Metade dos entrevistados que não citaram ações de forma concreta disseram que, apesar de saberem que elas existem, no momento não se lembravam de nenhuma.

\subsubsection{Critérios de escolha de uma loja virtual}

Sobre os principais critérios ao escolher uma loja virtual para comprar um eletrodoméstico da linha branca, todos os entrevistados citaram alguns, com destaque para: preço do produto; confiabilidade; prazo de entrega; já ser cliente, pela familiaridade com o site da empresa e rapidez e praticidade na hora da compra; preço do frete; políticas de troca; atendimento ou suporte ao cliente; e questões sociais ou ambientais que afetam a imagem da marca.

Diante da grande variedade de varejistas presentes na internet, supondo que o preço de um certo eletrodoméstico da linha branca fosse o mesmo entre todos eles, foi indagado aos entrevistados em qual loja virtual prefeririam comprar. As respostas foram:

- Magazine Luiza;

- Americanas;

- Ponto Frio;

- Fast Shop;

- Amazon;

- Submarino;

- Casas Bahia; 
- Shoptime;

- Loja virtual da Brastemp;

- Loja virtual da Electrolux.

Denota-se que 10 lojas virtuais foram mencionadas pelos entrevistados, que, juntos, somaram muitas respostas.

Quando perguntados o quanto mais caro pagariam por um eletrodoméstico da linha branca na loja virtual da Magazine Luiza, em vez de optarem por um de seus concorrentes, poucos entrevistados responderam que estariam dispostos a pagar um valor adicional. Destes, alguns disseram que dependeria do produto, do tipo de produto ou do quanto mais caro ele fosse. Outros declararam que poderiam pagar entre $5 \%$ e $10 \%$ a mais.

Como dito anteriormente, em uma pergunta semelhante, com esse questionamento, nosso objetivo era entender o quanto os entrevistados estariam dispostos a se fidelizar a empresas social ou ambientalmente responsáveis. Portanto, nossa expectativa era de que poucas pessoas citariam números absolutos ou porcentagens estipuladas.

\subsubsection{Perspectiva dos consumidores em relação à responsabilidade social da Magazine Luiza}

Notamos uma harmonia quase absoluta sobre a importância e admiração da Responsabilidade Social Corporativa nos relatos dos participantes. Porém, somente alguns conseguiram aprofundar, mesmo que minimamente, as suas respostas de forma objetiva. Isto posto, por ser um tema muito comentado nos dias atuais, talvez seja natural que as pessoas enxerguem a sua notoriedade, mas parece que não há verdadeiro interesse por parte dos indivíduos acerca da temática.

Segundo Teles (2018), "o atual egoísmo estabelecido entre os homens no ocidente tem muito a ver com o processo histórico de formação da presente sociedade ocidental. O homem pós-moderno ocidental hodierno mescla, em seu dia a dia, uma benevolência para com o outro e um egoísmo imensurável para consigo mesmo. Para uns, tal comportamento não é de somenos relevância, pois é preciso pensar nos outros, mas, sobretudo, antes de qualquer coisa, em si mesmo". O autor afirma, ainda, que no homem há duas paixões imbricadas: a benevolência e o autointeresse. Percebe-se, através das respostas, certa correlação dos temas citados às dores ou interesses de cada indivíduo e um 
certo desequilíbrio com a empatia e as necessidades das categorias que mais carecem de ações.

Possivelmente, se alguns entrevistados tivessem mais tempo para pensar ou pesquisar brevemente sobre os temas abordados, o resultado seria outro, mas não era isso o que se esperava neste estudo. $O$ objetivo se reserva a pontuar questões que realmente importavam, já que estas, presumivelmente, estão fundadas e claras na mente dos participantes e eles lembram com mais facilidade.

Porém, quando apresentados assuntos referentes à pandemia do Covid19, observamos maior aproveitamento das questões, eventualmente por se tratar de algo tão presente hoje e vivo nas mentes dos entrevistados. Quando perguntados sobre as ações da Magazine Luiza que se lembravam ou admiravam, todos citaram iniciativas do período pandêmico, como o programa de trainee para negros, que, apesar de não ter relação direta com a pandemia do Covid-19, foi lançado na mesma época. Isso talvez possa confirmar a ideia de que as pessoas estejam mais bem informadas ou interessadas pelo tema após a pandemia do Covid-19.

Um fato que chama atenção é que, em comparação com questões sociais, os tópicos de meio ambiente resultaram em um maior número de exemplos objetivos. E, quando perguntados que tipos de iniciativas os fariam dar preferência a uma empresa, a grande maioria das respostas se refere ao ambiente natural. Como a Magazine Luiza foi relacionada somente a ações sociais, pode haver alguma relação com o fato de que, quando perguntado, de modo genérico, se os participantes pagariam mais caro por um produto ou serviço de uma empresa social ou ambientalmente responsável, a maioria respondeu que sim. Já quando a questão se tratava de eletrodomésticos da linha branca na loja virtual da Magazine Luiza, poucos estariam dispostos a desembolsar um valor a mais. Existe, também, a possibilidade de as pessoas estarem mais acostumadas a pagarem mais caro por produtos sustentáveis, enquanto iniciativas sociais não geram tanto valor adicional a essa categoria e, consequentemente, os consumidores não enxergam tanto benefício.

Outro ponto relevante é que, quando os escândalos foram abordados, o número de respostas foi significativamente maior, tanto em valor absoluto quanto em variedade quando comparado às atitudes positivas das organizações. Notamos que eles estão mais vivos na memória dos participantes. Um exemplo disso é que quando perguntados sobre tipos de escândalos, boa parte dos entrevistados citou diversos exemplos sem que fossem solicitados. Logo, 
percebe-se que, apesar do engajamento moderado por boas práticas corporativas, as pessoas ficam altamente incomodadas com ações negativas das empresas, deixando de consumir ou admirar produtos ou serviços por elas disponibilizados.

Em relação aos critérios de escolhas de um varejista virtual, dentre vários citados, a grande maioria optou pelo preço como o mais importante. Quando indagados sobre a preferência entre os varejistas disponíveis na internet, a maioria elegeu a Magazine Luiza. Apesar de ser esse o resultado esperado, já que a pesquisa é limitada a consumidores dessa empresa, o que chama atenção é o elevado número de empresas mencionadas por eles. Portanto, na hora da compra, muitos entrevistados poderiam considerar outras companhias, o que demonstra a alta competitividade entre as varejistas no ambiente virtual e a baixa lealdade por parte do consumidor. 


\section{Conclusão}

O objetivo deste estudo foi compreender a percepção, o grau de influência e a fidelidade do consumidor na tomada de decisão de compra a partir da Responsabilidade Social Corporativa, considerando o impacto da pandemia do Covid-19. Além disso, o "novo normal", termo utilizado para representar a realidade pós-pandêmica, parece mostrar uma nova perspectiva sobre as ações esperadas das empresas. Sendo assim, como objetivos secundários, estão a possibilidade de compreender esse efeito e indicar que fatos podem confirmar a inevitabilidade das organizações em relação às boas práticas; e a análise dos principais perfis de consumidores que são mais ou menos afetados por práticas de Responsabilidade Social Corporativa, para que a Magazine Luiza e suas concorrentes, nesse contexto, escolham concentrar seus esforços para esse tipo de público.

Baseado no referencial teórico, realizamos uma pesquisa de caráter qualitativa, obtendo resultados sobre o comportamento do consumidor a partir de práticas socioambientais. Esse método de pesquisa foi escolhido, principalmente, pelo tempo disponível para a realização do trabalho. Porém, diante das respostas obtidas, presumimos que essa escolha tenha sido a mais adequada.

Por outro lado, caso fosse implementada uma pesquisa quantitativa, a partir das informações obtidas nesse estudo, podemos afirmar que os participantes concordariam com as boas práticas de Responsabilidade Social Corporativa. Mas talvez não chegássemos aos mesmos resultados aqui apresentados.

Quanto ao enfoque de análise, foram abordados os temas de Responsabilidade Social Corporativa dirigida aos grupos de interesse das organizações, à pandemia do Covid-19, ao comportamento do consumidor. Além de tratar desses assuntos, relacionando-os com a Magazine Luiza, para um melhor entendimento do cenário de estudo, o universo de compras on-line de eletrodomésticos da linha branca foi empregado.

Os resultados deste trabalho demonstram a relevância das práticas ambiental e socialmente responsáveis; a propensão de certos grupos de 
pessoas, com base nas características demográficas, às questões que tratam de suas dores ou interesses próprios; a superficialidade de informações da maioria das pessoas sobre a temática; maior interesse sobre o tema em um cenário póspandêmico; maior familiaridade dos consumidores com as ações de cunho ambiental, quando comparadas as de caráter social; grandes mudanças no comportamento do consumidor nos casos de escândalos ou comportamentos irresponsáveis das empresas; o preço como principal critério de escolha do consumidor no meio digital; e a falta de lealdade do consumidor on-line.

O presente estudo deixou certos questionamentos no ar. Logo, sugere-se pesquisas futuras mais aprofundadas e com amostras, por características mais abrangentes, para que se possa entender, de forma mais certeira, o objetivo central. Além disso, para eventuais estudos, faz-se necessário o acompanhamento dos avanços tecnológicos, de mudança em experiências de compra e de novas tendências, para que se possa levantar novas reflexões sobre o comportamento do consumidor, que está em constante transformação.

Este trabalho, portanto, também possui informações que podem ser importantes para outras empresas varejistas e até para outros setores. 


\section{Referências Bibliográficas}

10 ações para empresas diante de uma pandemia. Deloitte, 2020. Disponível em: <https://www2.deloitte.com/br/pt/pages/about-deloitte/articles/10acoes-empresas-pandemia.html>. Acesso em: 25 jun. 2020.

ACKOFF, R. A concept of corporate planning. New York: Wiley, 1970.

AGUINIS, H. Organizational responsibility: Doing good and doing well. Washington, DC: American Psychological Association, 2011.

AGUINIS, H.; GLAVAS, A. What We Know and Don't Know About Corporate Social Responsibility: A Review and Research Agenda. Journal of Menagement, v. 38, n.4, p. 932-968, jul. 2012.

AKREMI, A. E.; GOND, J. P.; SWAEN, V.; ROECK, K. D.; IGALENS, J. How Do Employees Perceive Corporate Responsibility? Development and Validation of a Multidimensional Corporate Stakeholder Responsibility Scale. Journal of Management, 2018. DOI: 10.1177/0149206315569311

ALVES, A. Magazine Luiza tem lucro no $1^{\circ}$ tri, com vendas online impulsionando receitas. Istoé Dinheiro, 2021. Disponível em: <https://www.istoedinheiro.com.br/magazine-luiza-tem-lucro/>. Acesso em: 16 maio 2021.

BASILIO, P. 7 ações que fizeram do Magazine Luiza a marca mais bem avaliada durante a crise. Gazeta do Povo, 2020. Disponível em: $<$ https://www.gazetadopovo.com.br/gazz-conecta/7-acoes-que-fizeram-domagazine-luiza-a-marca-mais-bem-avaliada-durante-crise/>. Acesso em: 15 jun. 2020.

BATISTA JR., J. Luiza Trajano pede aos comerciantes e empresários: “evitem demitir”. Veja, 2020. Disponível em: $<$ https://veja.abril.com.br/economia/luiza-trajano-pede-empresarios-naodemitam-coronavirus/>. Acesso em: 15 jun. 2020.

BHATTACHARYA, C.; SEN, S. Doing better at doing at good: when, why, and how consumers respond to corporate social initiatives. California Management Review, California, v.47, n.1, p.9-24, jan. 2004.

BOONE, L. E.; KURTZ, D. L. Marketing contemporâneo. 8. ed. Rio de Janeiro: LTC, 1998. 
BOSSE, D. A.; PHILLIPS, R. A.; HARRISON, J. S. Stakeholders, reciprocity, and firm performance. Strategic Management Journal, 30: 447456, 2009.

BRAMMER, S.; BRANICKI, L.; LINNENLUECKE, M. COVID-19, Societalization and the Future of Business in Society. Academy of Menagement Perspectives, jun. 2020.

Brazil Digital Report. 1aㅡ edição. McKinsey\&Company, 2019. Disponível em:<https://www.mckinsey.com/br/ /media/McKinsey/Locations/South\%20Ameri ca/Brazil/Our\%20Insights/Brazil\%20Digital\%20Report/Brazil-Digital-Report-1stEdition_Portuguese-vAjustado.pdf>. Acesso em: 25 nov. 2020.

Cadastro de Empregadores que tenham submetido trabalhadores a condições análogas à de escravo. Secretaria de Inspeção do Trabalho, 2020. Disponível em: <https://sit.trabalho.gov.br/portal/images/CADASTRO_DE_EMPREGADORES/C ADASTRO_DE_EMPREGADORES.pdf>. Acesso em: 10 jun. 2020.

CARROLL, A. B. A Three-Dimensional Conceptual Model of Corporate Performance. Academy of Management Review, v. 4, n. 4, p. 497-505, out. 1979.

CIALDINI, R. B.; GOLDSTEIN, N. J. Social influence: compliance and conformity. Annual Review of Psychology, 55, 591-621, 2004.

CLARKSON, M. A stakeholder framework for analyzing and evaluating corporate social performance. Academy of Management Review, 20: 92-117, 1995.

Compromisso com a sociedade. Magazine Luiza, s.d. Disponível em: <https://www.magazineluiza.com.br/quem-somos/compromisso-com-asociedade/?partner_id=39866\&gclid=CjwKCAjw-qeFBhAsEiwA2G7NI2WCWqpE-527e4-9qLsYJC9cxu4Ss35NLIhzoAsZhLq6XvRY7101hoCHRgQAvD_BwE>.

Acesso em: 20 maio 2021.

CREYER, E. H.; ROSS, W. T. The influence of firm behavior on purchase intention: do consumer really care about business ethics? Journal of Consumer Marketing, 14 (6), 421-433, 1997.

D'AURIA, G.; SMET, D. A.; GAGNON, C.; GORAN, J.; MAOR, D.; STEELE, R. Reimagining the post-pandemic organization. McKinsey \& Company, maio 2020.

ESKEROD, P.; HUEMANN, M.; SAVAGE, G. Project Stakeholder Management - Past and Present. Project Management Journal, v. 46, n. 6, p. 6-14, 2015. Publicado on-line em Wiley Online Library (wileyonlinelibrary.com). 
FERREIRA, D. A.; AVILA, M.; FARIA, M. D. Efeitos da responsabilidade social corporativa na intenção de compra e no benefício percebido pelo consumidor: um estudo experimental. Revista de Administração, São Paulo, v. 45, n. 3, p. 285-296, jul./ago./set. 2010.

FREEMAN, R. E. Strategic Management: A Stakeholder Approach. Pitman, 1984.

FRIEDMAN, M. The social responsibility of business is to increase its profits. The New York Times Magazine, set. 1970.

GINO, F.; AYAL, S.; \& ARIELY, D. Contagion and differentiation in unethical behavior: the effect of one bad apple on the barrel. Psychological Science, 20(3), 393-398, 2009.

GIOVANELLI, C. Após fechamento de canil clandestino, rede Petz deixa de vender filhotes. Veja São Paulo, 2019. Disponível em: <https://vejasp.abril.com.br/blog/bichos/rede-petz-deixa-vender-filhotes/>.

Acesso em: 11 jun. 2020.

GUIMARÃES, H. W. M. Responsabilidade social da empresa: uma visão histórica de sua problemática. Revista de Administração de Empresas, São Paulo, v. 24, n. 4, p. 211-219, out./dez. 1984.

KOTLER, P.; KARTAJAYA, H.; SETIAWAN, I. Marketing 4.0: do tradicional ao digital. Tradução: Ivo Korytowski. Rio de Janeiro: Sextante, 2017. 208 p. Título original: Marketing 4.0. ISBN 978-85-431-0533-8.

KOTLER, P.; KARTAJAYA, H.; SETIAWAN, I.; Marketing 3.0: as forças que estão definindo o novo marketing centrado no ser humano. Tradução: Ana Beatriz Rodrigues. Rio de Janeiro: Elsevier, 2010. Título original: Marketing 3.0. ISBN 978-85-352-4460-1

KOTLER, P.; KELLER, K. L. Administração em Marketing. Tradução: Mônica Rosenberg, Brasil Ramos Fernandes, Cláudia Freire. Revisão técnica: Dilson Gabriel dos Santos. 12. ed. São Paulo: Pearson Prentice Hall, 2006. Título original: Marketing management. ISBN 978-85-7605-001-8.

LIMA, J. 9 ações positivas do Magazine Luiza na pandemia. Yahoo! Finanças, 2020. Disponível em: <https://br.financas.yahoo.com/noticias/9-acoespositivas-do-magazine-luiza-na-pandemia-

080019499.html?guccounter=1\&guce_referrer=aHR0cHM6Ly93d3cuZ29vZ2xILm NvbS8\&guce_referrer_sig=AQAAACHXLCzMPJmcuqEgy25uJYz4Byobdjx7fQgR Dg_qCqAlo_caSgfhZ8dRtEQ75z_nUgsS5LTZsDjiqyDMIInxyW455lfBgEWgNLqC 74-I-PHu6Nj8Iw3EwLIljCaCJggIUgSleULXnz-CFbJXLMGNI6Z-

uh_2o_FmvrFWz9nBKeaR>. Acesso em: 8 abr. 2021. 
Magalu reforça campanha de botão de denúncia de violência contra a mulher em seu app. Mundo do Marketing, 2020. Disponível em $<$ https://www.mundodomarketing.com.br/ativacoes/37/magalu-reforcacampanha-de-botao-de-denuncia-de-violencia-contra-a-mulher-em-seuapp.html>. Acesso em: 5 jun. 2021.

MARCONI, M. A.; LAKATOS, E. M. Fundamentos de Metodologia Científica. 5. ed. São Paulo: Editora Atlas, 2003.

MARGOLIS, J. D.; ELFENBEIN, H. A.; WALSH, J. Does it pay to be good ... and does it matter? A meta-analysis of the relationship between corporate social and financial performance. Unpublished manuscript, 2009.

MARQUES, J. R. Conheça a História de Sucesso de Luiza Helena Trajano, da Rede Magazine Luiza. IBC Instituto Brasileiro de Coaching, 2020. Disponível em: <https://www.ibccoaching.com.br/portal/exemplo-delideranca/historia-sucesso-luiza-helena-trajano-magazine-luiza/>. Acesso em: 18 maio 2021.

MEDEIROS, M. A. História da Magazine Luiza: O Caminho Até a Transformação Digital. E-commerce de sucesso, 2021. Disponível em: <https://ecommercedesucesso.com.br/magazine-luiza-historia/>. Acesso em: 17 maio 2021.

MORGESON, F.; WALDMAN, D.; SIEGEL, D. Extending Corporate Social Responsibility Research to the Human Resource Management and Organizational Behavior Domains: A Look to the Future. Personnel Psychology. 2013.

NOLAN, J. M.; SCHULTZ, P. W.; CIALDINI, R. B.; GOLDSTEIN, N. J.; GRISKEVICIUS, V. Normative social influence is underdetected. Personality and Social Psychology Bulletin, 34(7), 913-923, 2008.

PACETE, L. G. Declarações de CEOs que pegaram mal. Meio \& Mensagem, 2017. Disponível em: <https://www.meioemensagem.com.br/home/marketing/2017/04/19/declaracoesde-ceos-que-pegaram-mal.html>. Acesso em: 12 jun. 2020.

PATI, C. Em 10 dias, Movimento Não Demita conquista adesão de 4 mil empresas. Você S/A, 2020. Disponível em: <https://vocesa.abril.com.br/mercado-vagas/movimento-nao-demita/>. Acesso em: 15 jun. 2020.

PENNER, L. A.; DOVIDIO, J. F.; PILIAVIN, J. A.; SCHROEDER, D. A. Prosocial behavior: Multilevel perspectives. Annual Review Psychology, 56, 365-392, 2005. 
PIVA JR., D. Sala de aula digital: uma introdução à cultura digital por educadores. 1. ed. São Paulo: Saraiva, 2013.

PORTER, M. E.; KRAMER, M. Creating shared value. Harvard Business Review, 89(1/2): 62-77, 2011.

RIBAS, R. T. M.; OLIVO, L. C. C. Adoção de Métodos Científicos como Componente. Metodologia e sua Explicitação nas Dissertações Publicizadas entre 2010 e 2014 de um Programa de Pós-Graduação em Administração. Revista de Ciências da Administração, v. 18, n. 44, p. 81-90, abr. 2016.

ROMANI, S.; GRAPPI, S. How companies' good deeds encourage consumers to adopt pro-social behavior. European Journal of Marketing, 48(5/6), 943-963, 2014.

RUPP, D. E.; GANAPATHI, J.; AGUILERA, R. V.; WILLIAMS, C. A. Employee reactions to corporate social responsibility: An Organizational Justice Framework. Journal of Organization Behavior, v. 27, n. 4, p. 537-543, jun. 2006.

SCHIFFMAN, L. G.; KANUK, L. L. Comportamento do consumidor. Tradução: Dalton Conde de Alencar. 9. ed. Rio de Janeiro: LTC, 2012. Título original: Consumer behavior, 9th Edition. ISBN 978-85-216-1684-9.

SCHUQUEL, T. Zara promoveu trabalho escravo e pode entrar para “lista suja". Metrópoles, 2017. Disponível em: <https://www.metropoles.com/brasil/justica/zara-promoveu-trabalho-escravo-epode-entrar-para-lista-suja?amp>. Acesso em: 11 jun. 2020.

SERPA, D. A. F.; FOURNEAU, L. F. Responsabilidade Social Corporativa: uma Investigação Sobre a Percepção do Consumidor. Revista de Administração Contemporânea, v. 11, n.3, jul./set. 2007.

SERRA, F.; TORRES, M. C. S.; TORRES, A. P. Administração Estratégica: Conceitos, Roteiro Prático e Casos. Rio de Janeiro: Reichmann \& Affonso, 2003.

SNEADER, K.; STERNFELS, B. From surviving to thriving: Reimagining the post-COVID-19 return. McKinsey \& Company, 2020.

SOLOMON, M. R. O Comportamento do Consumidor: Comprando, Possuindo e Sendo. Tradução: Beth Honorato. 11. ed. Porto Alegre: Bookman, 2016. Título original: Consumer Behavior: Buying, Having, and Being, 11th Edition. ISBN 9780133450897.

TELES, T. R. A "Ciência” do Egoísmo: breves críticas ao direito e ao homem (do) direito. Saber Humano, v. 8, n. 12, p. 31-53, jan./jul. 2018.

WENZEL, M.; STANKE, S.; LIEBERMAN, M. B. Strategic responses to 
crisis. Strat Mgmt J. 2020;41:V7-V18, abr. 2020.

ZACHO, R. O que é Marketplace? - veja as vantagens e desvantagens.

E-commerce Brasil, $2017 . \quad$ Disponível em:<https://www.ecommercebrasil.com.br/artigos/marketplace-vantagens-edesvantagens/>. Acesso em: 30 nov. 2020. 


\section{Anexo 1: Questionário}

\section{1aㅗ. seão:}

1. Nome?

2. Sexo?

3. Raça?

4. Quantos anos você tem?

5. Tem filhos?

$\underline{\text { Responsabilidade Social Corporativa orientada à comunidade }}$

6. O que você acha de empresas que investem em projetos sociais?

7. Que tipos de ações as empresas devem praticar para melhorar o bem-estar das populações nas áreas em que atua?

8. Além da obrigatoriedade do Estado, quais ações sociais você também acredita serem papel das empresas?

9. Quais empresas você admira ou se lembra que se preocupam com questões sociais?

$\underline{\text { Responsabilidade Social Corporativa orientada ao ambiente natural }}$

10. 0 que você acha de empresas que respeitam e promovem a proteção da biodiversidade e adotam comportamentos ecológicos?

11. Que tipos de ações ambientais você acredita que as empresas deveriam praticar?

12. Que empresas você admira ou se lembra que se preocupam com questões ambientais?

$\underline{\text { Responsabilidade Social Corporativa orientada ao colaborador }}$

13. Como você acha que as empresas devem se posicionar em relação ao bem-estar de seus funcionários?

14. Que tipos de ações você acredita que as empresas devam tomar em suas políticas de recrutamento e seleção? 
15. No caso de um fornecedor, subcontratado, prestador de serviço de uma empresa, onde quer que estejam, que medidas ela deve tomar para garantir que esses parceiros também se preocupem com ações de cunho social, ambiental ou de boas práticas com seus colaboradores?

$\underline{\text { Responsabilidade Social Corporativa dirigida à pandemia do Covid-19 }}$

16. Que tipos de assistências você admiraria, por parte de uma empresa, às pessoas mais necessitadas, em casos de desastres naturais, acidentes ou pandemias, como a do Covid-19?

17. Como você acha que as empresas devam se comportar em relação à sociedade em tempos de Covid-19?

18. Como você acha que as empresas devam se comportar em relação aos seus colaboradores em tempos de Covid-19?

$\underline{\text { Responsabilidade Social Corporativa dirigida ao Comportamento do Consumidor }}$

19. Ao comprar um produto ou serviço de uma empresa, que tipos de iniciativas de responsabilidade ambiental ou social fariam você dar preferência a ela?

20. Quais exemplos de escândalos de cunho socioambiental fariam você desistir de comprar um produto de uma empresa?

21. O quanto mais caro você pagaria por um produto ou serviço de uma empresa reconhecida por ações sociais ou ambientais em vez de escolher seu concorrente, que não se preocupa com questões do gênero?

\section{Compras on-line}

22. Qual foi a última vez que você fez uma compra on-line?

23. Quantas vezes, aproximadamente, você já comprou um eletrodoméstico da linha branca (geladeira, fogão, micro-ondas, máquina de lavar, ar-condicionado, entre outros) em lojas virtuais?

\section{2a secão:}

\section{$\underline{\text { Responsabilidade Social Corporativa e a Magazine Luiza }}$}

24. O que você acha da Magazine Luiza?

25. Quais práticas de cunho social ou ambiental da Magazine Luiza você se lembra?

26. Quais práticas de cunho social ou ambiental da Magazine Luiza durante a pandemia do Covid-19 você se lembra?

27. Quais práticas de cunho social ou ambiental da Magazine Luiza te fazem ter admiração pela empresa? 
28. Quantas vezes, aproximadamente, você já comprou um eletrodoméstico da linha branca (geladeira, fogão, micro-ondas, máquina de lavar, ar-condicionado, entre outros) na loja virtual da Magazine Luiza?

Critérios de escolha de uma loja virtual

29. Quais são seus principais critérios ao escolher uma loja virtual para comprar um eletrodoméstico da linha branca?

30. Entre a variedade de opções de varejistas on-line, supondo que o preço de um certo eletrodoméstico da linha branca seja o mesmo, entre todos, em quais lojas virtuais você preferiria comprar?

31. Até quanto você pagaria a mais por um eletrodoméstico da linha branca na Magazine Luiza em vez de escolher seu concorrente? 